\title{
Gravity survey on ice offshore South-East Greenland
}

\author{
S. S. Jakobsdóttir and H. C. Larsen
}

In the early spring an effort was made to extend some lines of marine gravity data from the shelf into the coast north of Ammassalik. A net of marine gravity data covers the shelf off East Greenland, reaching from about $59^{\circ} \mathrm{N}$ to $74^{\circ} \mathrm{N}$ (fig. 1). South of Scoresby Sund the gravity data are mostly collected in regions floored by oceanic crust, though some of the lines cross the ocean-to-continent boundary. Between Ammassalik and Scoresby Sund the oceanto-continent transition zone (OCT) runs close to the coast (Larsen, 1984), and is probably related to the onshore Tertiary basaltic dyke swarm described by Wager \& Deer (1938) and Myers (1980) (fig. 2). An offshore continuation of the dyke swarm was proposed by Larsen (1978). The aim of the gravity project was to obtain three tie-lines connecting the offshore marine gravity data to onshore gravity data to be obtained by the Geodetic Institute during the summer of 1986 (fig. 1). Such tie-lines would provide crucial information on the gravity field over the dyke swarm and might aid in a more precise location of the initial line of rifting in this region.

The survey area is covered with ice most of the year. Gravity surveys on ice have been carried out both in the Bothnian Bay (Lehmuskoski \& Mäkinen, 1978) and on ice-islands in the polar pack ice (Crary et al., 1952; Kristoffersen, 1982). Thus a helicopter survey with portable gravimeter and readings on the ice was planned for the South-East Greenland survey as this would provide gravity data from the area of interest at lowest cost. The ice cover off East Greenland is usually most extensive in April (Larsen, 1985) and the field operation was therefore scheduled for that month.

\section{The field operation}

The plan was to measure $35-45 \mathrm{~km}$ long lines (fig. 1), with a gravity station every third kilometre. A Bell 212 helicopter, stationed in Ammassalik, was chartered for the transport. The Omega navigation system in the helicopter was to be used for positioning the stations, with calibration by theodolite at the ends of the lines. A Lacoste-Romberg gravimeter, with special damping device for measuring on ice, was provided by the Finnish Geodetic Institute. The water depth was to be measured by an ELAC Echo-Sounder.

The survey area is difficult since it faces open sea. Furthermore a strong ocean current passes from the Denmark Strait causing a constant ice drift. Consequently, continuously frozen ice cover is only found near the coast.

When we arrived in Greenland on 10 April, an approximately $100 \mathrm{~km}$ wide ice belt stretched along the coast north of Ammassalik. Unfortunately a swell was found to roll through the ice belt with a period of 5-20 sec. and an amplitude of a few centimetres. This oscillation tilted the instrument back and forth by an angle of $0.05^{\circ}-0.1^{\circ}$. As the instrument is very sensitive to tilting, this was enough to make gravity readings impossible. Two attempts were made with a 24 hour interval without success. The oscillation was smaller the second day, but gravity readings were still impossible. 


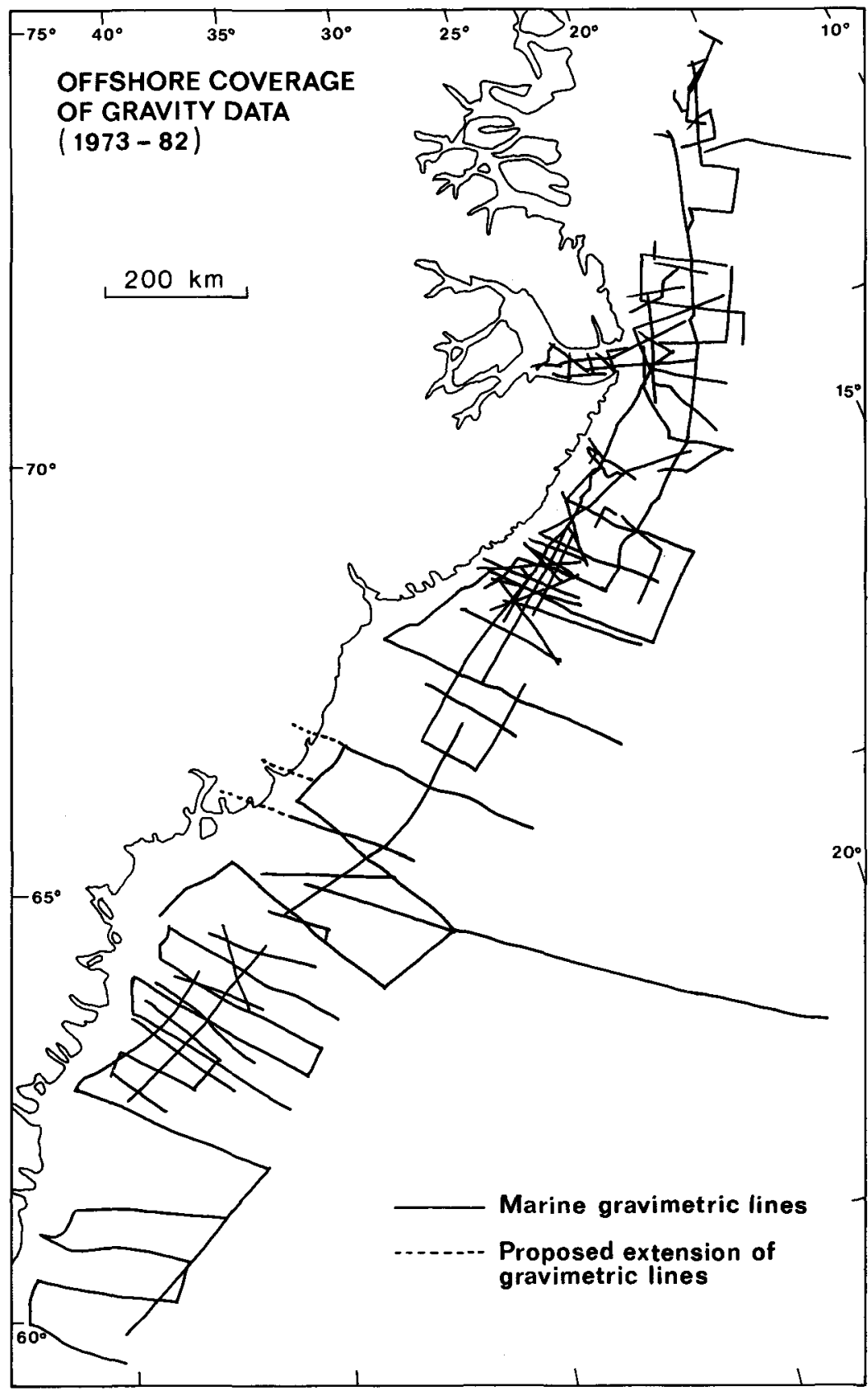

Fig. 1. Marine gravimetric coverage offshore East Greenland with proposed extension of some of the lines. 


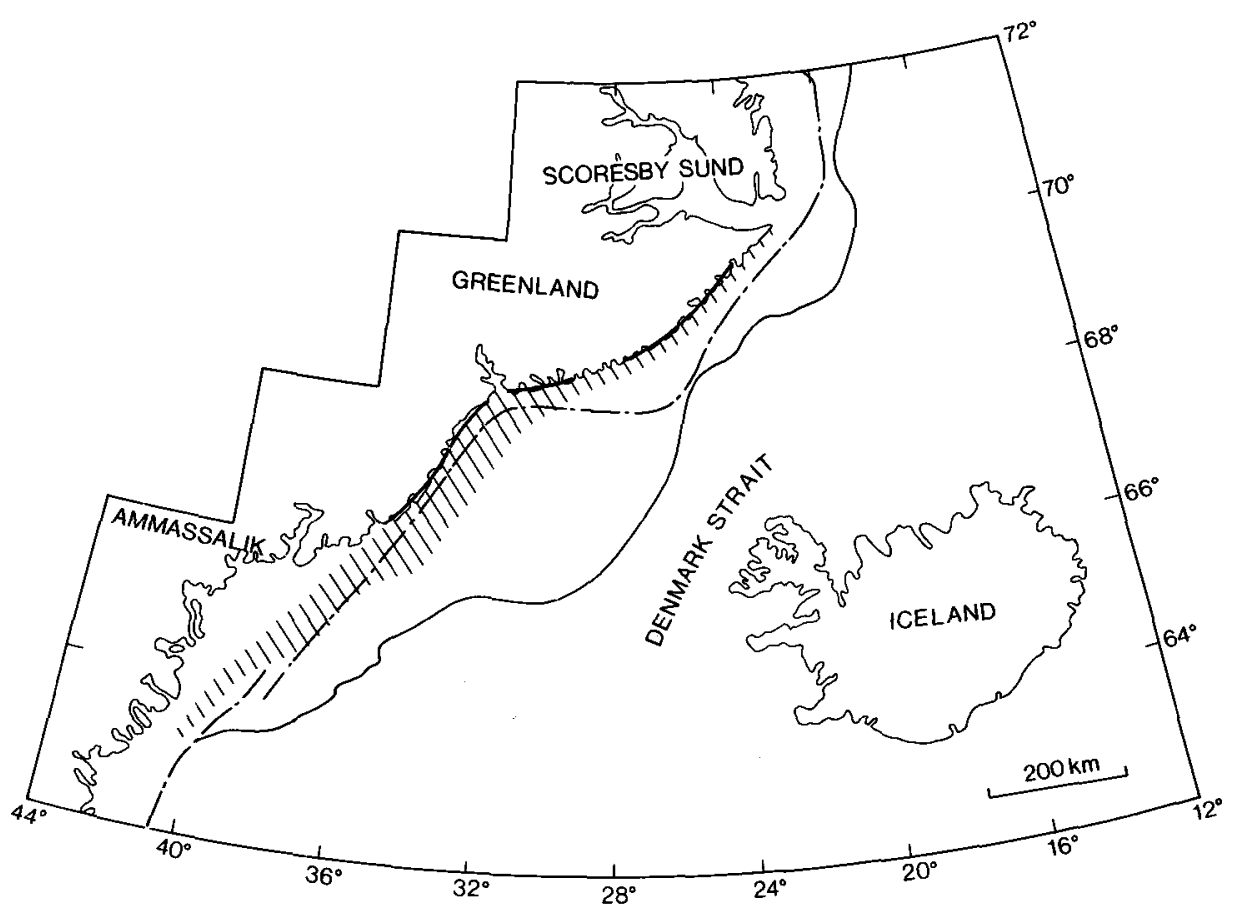

Fig. 2. The dyke swarm in East Greenland. The dyke swarms described by Wager \& Deer (1938) and Myers (1980) are shown with solid lines; the hatched area is the offshore continuation proposed by Larsen (1978). The ocean-to-continent transition zone (OCT) is shown with dash dot line and the shelf edge with thin solid line. The OCT and the shelf edge coincide south of $63^{\circ} \mathrm{N}$.

On the following days some experiments were made with gravity readings on the landfast ice in Ammassalik harbour. During a period of four days, the oscillations and movements of the instrument were registered once or twice a day in addition to gravity readings. These experiments support the conclusion that swells can be found many days after a storm (Jakobsdóttir \& Andersson, 1986).

\section{Conclusions}

The present study suggests that gravity readings in the study area with an ordinary portable gravimeter are impossible. Swells travel over long distances in an open ocean, so storms even many hundreds of kilometres away can influence the ice movements. Some kind of stabilised platform gravimeter is needed to collect gravity data under the given conditions. Readings with a marine gravimeter, either shipborne or transported by a helicopter landing on the ice, would be a technical possibility. Both methods are costly and, furthermore, a shipborne survey might have problems with drift ice all year round due to local and rather unpredictable drift ice concentrations along the coast. A third possibility would be an airborne gravimeter survey. This is, however, technically not a realistic possibility in the near future. 
Acknowledgements. The Finnish Geodetic Institute provided the gravimeter for the survey. Hauge Andersson and René Forsberg from the Danish Geodetic Institute collaborated in planning and carrying out this project.

\title{
References
}

Crary, A. P., Cotell, R. D. \& Oliver, J. 1952: Geophysical studies in the Beaufort Sea. Trans. Am. geophys. Un. 33, 211-216.

Jakobsdóttir, S. S. \& Andersson, H. 1986: Gravity measurements on ice offshore East Greenland. Unpubl. intern. GGU rep., 17 pp.

Kristoffersen, Y. 1982: US Icedrift Station FRAM 4. Report on the Norwegian field program. Rap. Norsk Polarinstitut 11, $60 \mathrm{pp}$.

Larsen, H. C. 1978: Offshore continuation of East Greenland dyke swarm and North Atlantic Ocean formation. Nature, Lond. 274, 220-223.

Larsen, H. C. 1984: Geology of the East Greenland Shelf. In Spencer, A. M. et al. (edit.) Petroleum geology of the North European Margin, 329-339. Graham \& Trotman Ltd., for the Norwegian Petroleum Society.

Larsen, H. C. 1985: Petroleum geological assessment of the East Greenland Shelf. Project NAD - East Greenland, final report. Report 8, $78 \mathrm{pp}$. Geological Survey of Greenland.

Lehmuskoski, P. \& Mäkinen, J. 1978: Gravity measurements on the ice of the Bothnian Bay. Geophysica 15,(1), 5-27.

Myers, J. S. 1980: Structure of the coastal dyke swarm and associated plutonic intrusions of East Greenland. Earth planet. Sci. Lett. 46, 407-418.

Wager, L. R. \& Deer, W. A. 1938: A dyke swarm and crustal flexure in East Greenland. Geol. Mag. 75, $39-46$.

\section{Studies of the onshore hydrocarbon potential in East Greenland 1986-87: field work from $72^{\circ}$ to $74^{\circ} \mathrm{N}$}

\author{
C. Marcussen, F. G. Christiansen, P.-H. Larsen, H. Olsen, S. Piasecki, L. \\ Stemmerik, J. Bojesen-Koefoed, H. F. Jepsen and H. Nøhr-Hansen
}

A study of the onshore hydrocarbon potential of central and northern East Greenland was initiated in 1986. Field work was carried out from early July to mid August covering the region between Kong Oscar Fjord and Kejser Franz Joseph Fjord (fig. 1). In 1987 field activities will continue further to the north, eventually reaching Danmarkshavn $\left(77^{\circ} \mathrm{N}\right)$.

The programme is a continuation of the 1982-83 investigations in Jameson Land (Surlyk, 1983; Surlyk et al., 1984a) and is part of a regional programme comprising petroleum geological studies of all sedimentary basins in Greenland (Larsen \& Marcussen, 1985; Larsen, 1986).

The aim of the two-year field study followed by laboratory analyses is:

(1) to study the presence and distribution of potential hydrocarbon source rocks in the region; 